\title{
Pijat Kaki dengan Losion Magnesium Menurunkan Stres Narapidana Perempuan
}

\section{Foot Massage Magnesium Lotion Decreasing Women Prisoners' Stress}

\author{
Giri Udani $^{1}$, Idawati Manurung ${ }^{2}$, Yulyuswarni ${ }^{3}$ \\ ${ }^{1,2}$ Jurusan Keperawatan, Politeknik Kesehatan Tanjungkarang, Indonesia \\ ${ }^{3}$ Jurusan Farmasi, Politeknik Kesehatan Tanjungkarang, Indonesia
}

\section{ARTICLE INFO}

\section{Article history}

Received date

05 Oct 2021

Revised date

12 Nov 2021

Accepted date

22 Nov 2021

Keywords:

Foot massage;

Magnesium lotion;

Stres.

\section{Kata kunci:}

Pijat kaki;

Losion magnesium;

Stres.

\begin{abstract}
ABSTRAK
Prisoners experience stress during detention, and this stress must be removed so that the behavior and mentality of prisoners can be quickly restored. Foot massage is one of the non-pharmacological therapies in stress management, which makes individuals more relaxed and able to avoid excessive stress reactions such as headaches, insomnia, anxiety, physical and mental fatigue. Magnesium is a mineral that plays an important role in the body's metabolism. Magnesium deficiency can cause migraines, insomnia, leg cramps, anxiety, arrhythmias, diabetes mellitus, and hypertension. Foot massage with magnesium lotion is expected to provide a relaxing effect as well as magnesium intake so that it can overcome the stress experienced by prisoners. This study aims to determine the effect of foot massage magnesium lotion on the stress level of female prisoners. The research method is a quantitative quasi-experimental design with a pre-test-post-test approach on 120 female prisoners by comparing stress levels before and after doing foot massage with magnesium lotion for 14 days. Foot massage with magnesium lotion is done independently. Based on the results of the study, there was a significant difference between stress levels before and after the intervention, there was no significant difference between the stress levels of respondents who had long been detained and those who had just been detained. Multivariate analysis showed that the main factor in stress levels was the sentence period. Foot massage using magnesium lotion is a supporter of reducing stress levels. This therapy should still be done because it helps reduce stress and is carried out independently by prisoners.
\end{abstract}

Narapidana mengalami stres selama masa tahanan, dan stres ini harus dihilangkan agar perilaku dan mental narapidana bisa cepat dipulihkan. Pijat kaki merupakan salah satu terapi non farmakologi dalam penatalaksanaan stress, yang membuat individu lebih relaks dan mampu menghindari reaksi berlebihan stres seperti, sakit kepala, insomnia, kecemasan, kelelahan fisik dan mental. Magnesium merupakan salah satu mineral yang berperan penting dalam metabolisme tubuh. Defisiensi magnesium dapat mengakibatkan migrain, insomnia, kaki kram, anxiety, aritmia, diabetes mellitus, dan hipertensi. Pijat kaki dengan losion magnesium diharapkan dapat memberikan efek relaksasi sekaligus intake magnesium sehingga dapat mengatasi stres yang dialami narapidana. Penelitian ini bertujuan untuk mengetahui adanya pengaruh pijat kaki dengan losion magnesium terhadap tingkat stres narapidana wanita. Metode penelitian kuantitatif quasi eksperimental design dengan pendekatan pretest-posttest pada 120 orang narapidana wanita dengan membandingkan tingkat stres sebelum dan sesudah melakukan pijat kaki dengan magnesium lotion selama 14 hari. Pemijatan kaki dengan losion magnesium dilakukan secara mandiri. Ada perbedaan bermakna antara tingkat stres sebelum dan sesudah intervensi, tidak ada perbedaan yang bermakna antara tingkat stres responden yang sudah lama dengan yang baru ditahan, Analisa mulitivariat menunjukkan faktor utama tingkat stres adalah vonis masa hukuman. Pijat kaki menggunakan losion magnesium menjadi pendukung penurunan tingkat stres. Terapi ini sebaiknya tetap dilakukan karena membantu menurunkan stres dan dilakukan dengan mandiri oleh narapidana.

Corresponding Author:

Giri Udani

Jurusan Keperawatan Poltekkes Tanjung Karang, Indonesia

Email: giriudani@poltekkes-tjk.ac.id 


\section{PENDAHULUAN}

Stres tidak ditangani akan memberikan efek jangka panjang yang berdampak timbulnya penyakit, gangguan somatik, gangguan kesehatan, dan gangguan fungsi sosial. Stres yang dirasakan oleh individu menimbulkan upaya untuk melakukan reaksi terhadap stres yang dialaminya. Secara umum, stres terjadi jika individu dihadapkan dengan peristiwa yang dirasakan sebagai ancaman bagi kesehatan fisik atau psikologis. Individu yang mengalami stres menimbulkan dampak baik dari aspek fisik, emosional/psikologis, kognitif dan respon sosial (Wulan, 2018).

Seorang wanita yang berada di lapas akan mengalami stres. Kondisi stres narapidana salah satu penyebabnya karena terbatasnya perilaku akibat kepadatan dan isolasi dari masyarakat, serta terbatasnya ruang personal, sehingga narapidana cenderung merasa sesak akan kondisi tersebut. (Sarah, 2019; Utomo \& Kurniati, 2020). Salah satu metode terapi yang digunakan untuk menghasilkan relaksasi nonfarmakologi menurut Trisnowiyanto (2012) dengan memberikan masase pada area kaki dapat memperlancar sistem peredaran darah. Pijatan memberikan efek kenyamanan, sedatif dan mampu merangsang sistem saraf dan meningkatkan aktifitas otot, sehingga pijatan pada kaki dapat mengendurkan otot-otot yang membuat pasien menjadi relaks. Pijatan merangsang produksi hormon endorpin yang berfungsi untuk relaksasi danmengurangi beban yang ditimbulkan akibat stres (Nuraini, 2019). Pijat kaki bermanfaat untuk mengurangi kecemasan, stres, dan nyeri yang dirasakan oleh pasien, sekalipun pijatan diberikan dalam waktu yang pendek dan hanya pada bagian kaki saja, memberikan manfaat seperti hati menjadi lebih tenang, stres berkurang dan peningkatan pada tidur (Oshvandi, et al., 2021).

Magnesium sebagai kofaktor enzimatik berperan dalam metabolism ATP, sintesa DNA dan RNA, reproduksi dan sintesa protein. Selain itu magnesium penting untuk kontraksi otot, tekanan darah, metabolisme insulin, ransangan jantung, tonus vasomotor dan transmisi syaraf dan konduksi neuromuscular. Kebutuhan magnesium harian orang dewasa adalah 300$420 \mathrm{mg}$, tetapi dengan gaya hidup masyarakat modern saat ini, sulit untuk memenuhi kebutuhan magnesium hanya dari makanan. Oleh karena itu penambahan magnesium secara intravena maupun transdermal akan membantu kecukupan magnesium di dalam tubuh. (Kenner, 2019; Yulyuswarni, 2021). Beberapa masalah kesehatan muncul di sebabkan kekurangan magnesium seperti aritmia, anxiety, kram, katarak, hipertensi, migrain, osteoporosis, vertigo, tremor, photosensitivitas dan lain-lain (DiNicolantonio, et al., 2018). Suplementasi magnesium menunjukkan manfaat dalam pengobatan antara lain, preeklamsi, migrain, depresi,penyakit arteri koroner, dan asma (Kass et al., 2017). Terapi magnesium topikal merupakan salah satu terapi yang sudah lama digunakan seperti terapi berendam air garam dipercaya mampu menghilangkan pegal-pegal dan relaksasi, dan sampai saat ini masih banyak dilakukan di masyarakat. Setelah mengaplikasi topikal magnesium, magnesium menembus stratum korneum manusia tergantung jumlah konsentrasi dan lamanya waktu paparan dan folikel rambut memberikan kontribusi signifikan terhadap penetrasi magnesium (Chandrasekaran, et al., 2016; Yulyuswarni, 2021). Pemberian losion magnesium disamping sebagai pelumas pada saat pijat kaki sekaligus memberikan intake magnesium secara transdermal, sehingga diharapkan meningkatkan nilai kemanfaatan sediaan. Formulasi losion magnesium sebagai suplemen magnesium secara transdermal merupakan sediaan cosmeceutical bernilai ekonomi dan bermanfaat menurunkan tingkat stres (Yulyuswarni, 2021). Dari beberapa penelitian, diketahui bahwa mineral nutrisi dalam air dapat diserap kulit. Setelah aplikasi transdermal dua belas minggu dengan larutan magnesium klorida jenuh $31 \%$, terjadi peningkatan rata-rata kadar magnesium seluler $59,5 \%$ pada $89 \%$ subjek uji. Semua peserta menunjukkan peningkatan rata-rata $25,2 \%$ dalam rasio kalsium-magnesium selama periode uji. Sebuah uji klinis in vitro yang dilakukan di University of Cardiff membuktikan bahwa unsur magnesium dapat dikirim ke sel-sel tubuh melalui pengiriman transdermal. Percobaan menunjukkan bahwa kulit mulai terserap dengan efek langsung dan akselerasinya dipercepat dengan memijat area aplikasi setelah menyemprotkan larutan magnesium ke kulit (Heard, 2011).

Peningkatan jumlah Warga Binaan Pemasyarakatan (WBP) terjadi terus, tahun 2016, total 204 orang. Tahun 2017, total 232 Orang. Pada tahun 2018, total 247orang (UPT Permasyarakatan, 2018). Menjalani kehidupan di lapas merupakan perubahan kehidupan bersifat ekstrim karena seseorang terpidana yang menjalani pidana akan hilang kemerdekaan dan mengalami stres yang Panjang. Hasil Penelitian Nuria (2016) di Lembaga Pemasyarakatan Kelas II.A Kota Jember 22 orang (73\%) narapidana 
mengalami stres sedang dan penelitian Anggit (2017) penelitian Dilembaga Pemasyarakatan Kelas II.A Kota Bogor (49 orang) $83 \%$ narapidana wanita mengalami stres ringan. Banyak terapi dilakukan dilapas, yang bertujuan memulihkan mental dan perilaku narapidana (Abdullah, 2020). Kebanyakan terapi berupa konseling individu maupun kelompok, tetapi kebanyakan terapi dilakukan saat mereka akan keluar sel dan diajarkan oleh orang lain. Semua terapi bertujuan menghilangkan stres (Buahatika, 2019). Stres yang tidak teratasi bisa berkembang menjadi depresi, perilaku agresif, konflik dengan sesame narapidana atau petugas dan pemulihan emosi, mental dan perilaku bisa terhalang. Kondisi ini juga bisa menular pada keluarga karena keluarga menjadi sasaran kemarahan atau kesedihan narapidana.

Terapi ke arah kejiwaan seperti konseling dan terapi kelompok mampu menurunkan stres. (Manurung, et al., 2020). Tetapi karena jumlah narapidana banyak, dan konselor sangat sedikit sehingga akan membutuhkan banyak waktu dan tenaga bila memakai metoda konseling dan terapi kelompok. Jadi harus ada acara yang efektif untuk menurunkan stres dan bisa dilakukan sewaktu-waktu, tidak memerlukan ahli serta dapat dilakukan secara mandiri. Terapi pijat kaki ini merupakan salah satu cara yang efektif. Riset ini berfokus mengetahui pengaruh pijat kaki dengan losion magnesium terhadap tingkat stres narapidana wanita di Lembaga Pemasyarakatan Wanita Klas II.A Bandar Lampung dengan tujuan mengetahui karakteristik responden, frekuensi pijatan dan tingkatan stres sebelum dan sesudah intervensi pijatan pada kaki serta faktor yang paling mempengaruhi tingkat stres.

\section{METODE}

Jenis penelitian ini adalah penelitian kuantitatif dengan desain quasi eksperimental, rancangan one-group pre-post-test design bertujuan melihat pengaruh foot massage dengan menggunakan magnesium lotion terhadap stres narapidana wanita.. Penelitian dilaksanakan pada bulan April-Desember 2020 di Lembaga Permasyarakatan Wanita Kelas IIA, Lampung. Populasi penelitian ini sebanyak 315 orang narapidana wanita, dan sampel 120 orang. Penelitian ini mendapat izin layak etik dari Komisi Etik Poltekkes Tanjungkarang. Kuesioner diujicobakan dulu pada narapidana di tempat yang sama, yang tidak terpilih menjadi responden karena tidak sesuai dengan kriteria inklusi.

Teknik pengumpulan data dibagi menjadi beberapa tahap persiapan/praintervensi, tahap intervensi dan tahap postintervensi. Tahap persiapan (pembuatan leafet dan video, pembuatan kuesioner tentang stres dan pembuatan losion magnesium). Enumerator dilatih pijat kaki dan cara pemakaian losion. Tahap pra intervensi, kuesioner diberikan kepada narapidana yang sudah ditahan minimal 1(satu) tahun, dewasa, dan menikah. Responden dilatih pijat kaki menggunakan losion magnesium. Setelah mereka dianggap dapat melakukan dengan teknik yang benar, maka responden diberikan losion yang mereka pakai untuk melakukan pijat kaki disaat stres timbul, baik di malam hari atau siang hari. Setiap kali narapidana merasakan stres, mereka memijat kakinya dengan losion magnesium. Kemudian narapidana dianjurkan melakukan pijat kaki, yang bisa dilakukan sendiri atau meminta bantuan temannya, antar responden minimal dua kali sehari atau bila sedang stres, tiga kali sehari. Panduan ada pada leaflet yang dibagikan. Penelitian ini membuat responden melakukan terapi sendiri/mandiri, dengan waktu tidak terbatas (bebas waktunya) dan disesuaikan dengan kondisi diri responden. Terapi pijat kaki dengan losion magnesium menjadi salah satu alternatif menurunkan stres sampai mereka punya waktu dan keberanian untuk konseling atau menyelesaikan masalah mereka dengan teknik lain. Tahap post-test dilakukan pengukuran respon stres dengan membagikan kuesioner setelah Intervensi pijat kaki secara mandiri yang sudah dilakukan selama 2 minggu.

\section{HASIL}

Tabel 1. Distribusi frekuensi karakteristik responden

\begin{tabular}{lccc}
\hline Aspek & Mean & SE & SD \\
\hline Umur (tahun) & 36,03 & 2,00 & 11,35 \\
$\begin{array}{l}\text { Vonis Masa Tahanan } \\
\text { (bulan) }\end{array}$ & 69,56 & 8,33 & 47,16 \\
$\begin{array}{l}\text { Masa Tahanan yang } \\
\text { telah dijalani (bulan) }\end{array}$ & 15,6 & 0,91 & 5,15 \\
$\begin{array}{l}\text { Frekuensi Pijat kaki } \\
\text { (kali) }\end{array}$ & 23,5 & 0,48 & 5,33 \\
\hline
\end{tabular}

Berdasarkan data pada tabel 1 menunjukkan bahwa karakteristik responden rata-rata umur responden 36,03 tahun, rata-rata masa hukuman tahanan 69,56 bulan (5-6 tahun), rata-rata masa tahanan yang telah dijalani 15,6 , bulan (2-3 tahun) dan rata-rata telah melakukan pijat kaki sebanyak 23 kali. 
Tabel 2. Distribusi Frekuensi Tingkat Stres pada Responden Sebelum dan Sesudah Intervensi Pijat Kaki dengan Losion Magnesium

\begin{tabular}{lrrrr}
\hline \multirow{2}{*}{$\begin{array}{c}\text { Tingkat } \\
\text { stres }\end{array}$} & \multicolumn{2}{c}{$\begin{array}{c}\text { Sebelum } \\
\text { Tindakan }\end{array}$} & \multicolumn{2}{c}{$\begin{array}{c}\text { Sesudah } \\
\text { Tindakan }\end{array}$} \\
\cline { 2 - 5 } & Frekuensi & \% & Frekuensi & \% \\
\hline Stres & 62 & 51,7 & 103 & 85,8 \\
Rendah & & & 17 & 14,2 \\
Stres & 58 & 48,3 & & \\
Tinggi & & & & \\
\hline
\end{tabular}

Berdasarkan data pada tabel 2, didapat sebelum intervensi tingkat stres rendah, sebanyak 62 orang $(51,7 \%)$ sedangkan tingkat stres tinggi, 58 orang $(48,3 \%)$ Setelah intervensi, tingkat stres rendah sebanyak 103 orang $(85,8 \%)$ dan tingkat stres tinggi sebanyak 17 orang $(14,2 \%)$.

Tabel 3. Perbedaan Rata-Rata Tingkat Stres pada Responden Sebelum dan Sesudah Intervensi Pijat Kaki dengan Losion Magnesium

\begin{tabular}{lccccc}
\hline Kondisi & Mean & SD & SE & $\begin{array}{c}p- \\
\text { value }\end{array}$ & n \\
\hline $\begin{array}{l}\text { Sebelum } \\
\text { Tindakan }\end{array}$ & 63,68 & 13,30 & 1,21 & & \\
$\begin{array}{l}\text { Sesudah } \\
\text { Tindakan }\end{array}$ & 21,11 & 16,07 & 1,46 & 0,00 & 120 \\
\hline
\end{tabular}

Rata-rata stres saat sebelum intervensi pijatan adalah 63,68 dengan SD 13,30. Sesudah intervens pijatan, 21,11 dengan SD 16,07. Ratarata perbedaan stres antara sebelum dengan sesudah intervensi pijatan 42,57 dengan SD 21,32. Hasil uji didapatkan nilai 0,00 maka disimpulkan ada perbedaan yang bermakna antara stres sebelum dengan sesudah intervensi.

Tabel 4. Distribusi Masa Tahanan

\begin{tabular}{lccccc}
\hline $\begin{array}{c}\text { Masa } \\
\text { Tahanan }\end{array}$ & Mean & SD & SE & $\begin{array}{c}p- \\
\text { value }\end{array}$ & $\mathbf{n}$ \\
\hline $\begin{array}{l}\text { Selama } \leq 2 \\
\text { tahun }\end{array}$ & 22,84 & 14,46 & 2,55 & & \\
$\begin{array}{l}\text { Lebih dari } \\
2 \text { tahun }\end{array}$ & 20,48 & 16,65 & 1,77 & 0,478 & 120 \\
\hline
\end{tabular}

Tabel 4 menunjukkan rata-rata tingkat stres pada masa tahanan selama $\leq 2$ tahun), 22,84 dengan SD 14,46 sedangkan pada masa tahanan lebih dari 2 tahun didapatkan 20,48 dengan SD 16,65 . Nilai $p$-value $=0,478$, lebih dari 0,05 , berarti pada alpha 0,05 didapatkan tidak ada perbedaan varian (varian sama). Nilai $p$-value yang dipakai pada varian yang sama yaitu 0,478 , artinya tidak ada perbedaan yang bermakna antara stres responden yang sudah di dalam penjara selama $\leq 2$ tahun dengan yang sudah lebih dari 2 tahun. Berdasarkan hasil analisis multivariat antara variabel vonis masa tahanan, masa tahanan yang sudah dijalani, umur dan frekuensi pijat, yang paling mempengaruhi tingkat stres narapidana setelah intervensi pijat kaki dengan losion magnesium adalah vonis lamanya masa hukuman setelah dikontrol umur, masa tahanan yang telah dilewati dan frekuensi pijat kaki yang dilakukan

\section{PEMBAHASAN}

Berdasarkan pada tabel 1 hasil analisa karakteristik responden didapatkan bahwa sebagian besar responden adalah dimasa umur produktif menghasilkan uang atau karir, masamasa membesarkan anak dan masa mempertahankan pernikahan sehingga peristiwa masuk lapas menjadikan responden mengalami stres yang luar biasa bagi kehidupan mereka. Perpisahan dengan anak, kehilangan pekerjaan, kesetiaan pasangan, persaingan hidup dalam lapas, pengawasan ketat dan kehilangan privasi, semakin membuat stres (Kurniawati, 2019). Apalagi ada beban ekonomi dan lingkungan lapas yang tidak menyenangkan, sehingga menyebabkan stresor semakin bertambah bagi narapidana (Agus, 2020). Itulah yang membuat narapidana stres, ditambah lagi ada kejenuhan akan kegiatan yang rutin dan tingkat persaingan yang tinggi satu sama lain.

Tingkatan stres semakin terlihat pada tabel 2, dimana hampir sebagian besar narapidana memiliki stres tinggi, dengan rata-rata sudah 2-3 tahun di lapas dan masih lama untuk keluar, jadi faktor kejenuhan dan perpisahan dengan keluarga sudah sangat besar (Siregar, et al., 2019). Bila dibandingkan dengan hasil antara yang sudah lebih dua tahun di lapas dengan yang kurang dari dua tahun di lapas, ternyata tidak ada perbedaan yang bermakna. Kehidupan di lapas tetap menjadikan hidup narapidana penuh dengan stres walau sebentar atau sudah lama (Anggit \& Ni, 2017). Ditambah lagi jarang dibesuk, ditinggal keluarga atau pasangan, rasa dendam, kebencian terhadap orang-orang yang dianggapnya menjadi penyebab mereka harus ditahan. Stres datang bisa datang sewaktu-waktu, mereka tidak bisa mencurahkan perasaannya dengan sesama karena mereka juga punya masalah yang sama. Ingin koseling, tidak bisa dikarenakan waktu terbatas yang dijadwalkan di siang hari saja, tenaganya terbatas dan sungkan karena takut semakin dipojokkan, dan disalahkan.

Narapidana yang sudah stres di sepanjang hidupnya sebelum masuk lapas, mereka memilih 
koping yang tidak konstruktif dan mengambil keputusan yang salah sehingga membuat mereka masuk penjara. Kehidupan dipenjara membuat mereka mengalami stres berkepanjangan, tetapi tidak semua menjadi stres tinggi karena proses adaptasi membuat mereka bisa menjalani hidup dan juga kehidupan di penjara dirasakan sudah lebih manusiawi bagi mereka.

Pada tabel 3 menunjukkan bahwa rata-rata tingkat stres menurun setelah intervensi pijat kaki dengan losion magnesium. Penurunan ini bisa disebabkan adanya pijatan pada kaki yang menurunkan kadar stres karena adanya proses relaksasi pada segi mental dan fisik. Pemijatan area kaki menimbulkan sirkulasi darah pada kaki lancar, rasa pegal-pegal hilang, dan suasana hati lebih relaks, sehingga menurunkan kecemasan dan respon fisik narapidana yang mengalami stres menurun. Pijat kaki dengan losion magnesium yang dilakukan memberikan dampak relaksasi dan pengaruh terhadap suasana hati narapidana. Pemijatan bisa menurunkan kecemasan dan juga relaksasi otot (Suwanto, et al., 2020). Pijatan atau massase dapat menurunkan denyut jantung dan tekanan darah, melemaskan otot dan meningkatkan endorphin, hormone alami tubuh yang dapat menimbulkan rasa nyaman. Serotonin dan dopamin juga dikeluarkan melalui pijatan dan menimbulkan perasaan relaksasi yang membuat rasa tenang, sehingga stres pun dapat lebih mudah untuk diatasi. Selain itu Pijat refleksi merupakan suatu praktik memijat titik-titik tertentu pada tangan serta kaki. khasiatnya yang paling populer yaitu untuk mengurangi rasa sakit pada tubuh, mencegah berbagai penyakit, meningkatkan daya tahan tubuh, membantu mengatasi stres, meringankan migraine, membantu penyembuhan penyakit kronis, dan mengurangi ketergantungan terhadap obat-obatan (Ruhito \& Mahendra, 2019). Hasil analisa jurnal tentang efektivitas terapi pijat kaki bahwa terdapat hasil yang efektif dalam penerapan terapi pijat kaki pada pasien dengan hipertensi, diabetes mellitus, gangguan tidur, insomnia, nyeri pada disminore dan rematik, serta kecemasan (Sari, 2021).

Perbedaan penurunan rata-rata tingkat stres sebelum dan setelah intervensi pijat kaki dengan losion magnesium hal ini dapat terjadi karena dimungkinkan terjadi relaksasi setelah diberikan intervensi pijat kaki dengan losion magnesium sehingga menurunkan tingkat stres pada warga binaan. Losion magnesium lebih efektif menurunkan stres dari pada magnesium peroral, karena lebih cepat diserap dan tidak menimbulkan dampak samping pada saluran cerna bila dibandingkan dengan peroral (Werner, et al., 2017). Pijatan diantaranya melancarkan peredaran darah, merangsang effisiensi otot (kemampuan guna otot) dan mengaktifkan syaraf sadar dan kerja syaraf otonom sehingga menghasilkan rasa relaks pada fisik dan stres berkurang. Pijat kaki tidak saja memberikan kenyamanan, menurunkan kecemasan dan stres (aspek mental) juga dapat memberikan pengaruh positif pada aspek fisik dan penyakit-penyakit tertentu seperti tekanan darah, penyakit jantung dan edema kaki. (Arianto et al., 2018; Tiara \& Lestari, 2013).

Pemberian losion magnesium secara transdermal hal ini memungkinkan asupan magnesium yang dibutuhkan tubuh meningkat, dimana pemberian suplemen magnesium transdermal dapat diserap oleh kulit yang banyak mengandung pembuluh darah sehingga dapat menurunkan tingkat stres setelah diberikan pijat kaki menggunakan losion magnesium. Hal ini di dukung dari hasil beberapa penelitian, bahwa mineral nutrisi dalam air dapat diserap kulit. Sebuah uji klinis in vitro yang dilakukan di University of Cardiff yang membuktikan bahwa unsur magnesium dapat dikirim ke sel-sel tubuh melalui pengiriman transdermal. Menunjukkan bahwa kulit menyerap dengan efek langsung dan akselerasinya dipercepat dengan mengaplikasikan magnesium setelah menyemprotkan larutan magnesium ke kulit (Gröber, et al., 2017). Defisiensi magnesium dapat memberikan dampak yang banyak diantaranya stres dan depresi, dengan pemberian magnesium dapat menurunkan stres dan depresi. Magnesium merupakan suplemen mineral yang dapat membantu mengurangi gejala depresi karena merubah suasana hati dan otak (Gröber, et al., 2017).

Magnesium sebagai kofaktor lebih dari 300 sistem enzim yang mengatur reaksi biokimia yang beragam dalam tubuh, termasuk sintesis protein, untuk otot dan fungsi saraf, mengatur kadar glukosa darah, dan regulasi tekanan darah. Magnesium memainkan peran fisologis yang penting, terutama di otak, jantung, dan otot rangka. Suplementasi magnesium telah terbukti bermanfaat dalam pengobatan antara lain, preeklamsi, migrain, depresi, penyakit arterikoroner, dan asma (Kass et al., 2017).

Berdasarkan dari hasil analisis diketahui pada tabel 4 menunjukkan rata-rata tingkat stres pada masa tahanan selama $\leq 2$ tahun) didapatkan 22,84 (tingkat stres ringan) dengan SD 14,46 sedangkan pada masa tahanan lebih dari 2 tahun didapatkan 20,48 (tingkat stres ringan) dengan SD 16,65. Nilai $p$-value $=0,478$ berarti lebih dari 0,05 , yang berarti pada alpha 0,05 didapatkan tidak ada perbedaan pada varian (varian sama). 
Nilai $p$-value yang dipakai pada varian yang sama yaitu 0,478 , artinya tidak ada perbedaan yang bermakna antara stres responden yang sudah didalam penjara selama $\leq 2$ Tahun dengan yang lebih dari 2 tahun.

Pada analisa multivariat antara faktor vonis masa tahanan, faktor masa tahanan yang sudah dilewati dan dengan faktor usia setelah intervensi pijat kaki dengan losio magnesium di Lembaga Pemasyarakatan Perempuan Kelas IIA Lampung. adalah vonis masa tahanan. Melihat koefisein Beta Stres $=29,7+0,08$ masa tahanan $-5,28$, masa tahanan yang sudah dijalani $+0,016$ umur, maka yang paling berat pengaruhnya terhadap strss narapidana adalah masa tahanan. Hal ini dimungkinkan karena keputusan hukuman yang ditetapkan menjadikan stresor bagi narapidana sehingga menimbulkan stres yang secara umum dari hasil pre-test didapatkan pada tingkat stres sedang $(63,68)$, setelah dilakukan intervensi pijat kaki dengan losion magnesium didapatkan tingkat stres ringan $(21,11)$ hal ini membuktikan bahwa masa tahanan berpengaruh terhadap narapidana karena menjalani masa hukuman narapidana sering mengalami hambatanhambatan dalam upaya memenuhi kebutuhankebutuhannya, baik biologis maupun psikologis. Sesuai pendapat Welta dan Agung (2017) mengungkapkan bahwa masa hukuman menyebabkan narapidana mengalami banyak kehilangan seperti kehilangan pekerjaan, kehilangan pelayanan pribadi, kehilangan kenyamanan dan kehilangan kebebasan. Menurut Siswati, et al. (2007) terdapat hubungan positif yang sangat signifikan antara lama menjalani hukuman dengan kondisi stres narapidana. Lamanya masa tahanan menyumbang $57,5 \%$ terhadap kondisi stres, sedangkan sisanya berasal dari faktor lain yaitu seperti faktor jenis kelamin, usia, jenis kasus, latar belakang lingkungan sosial, tingkat pendidikan, dan lain sebagainya .

Hambatan pada riset ini adalah masa pandemik, peneliti tidak bisa lagi kontak lansung dengan responden karena pembatasan jarak, sehingga pelaksanaan pemantau intervensi sepijat kaki semua dipandu oleh enumerator. Peneliti hanya bisa memberikan losion melalui petugas. Peneliti tidak bisa memantau secara langsung kesan-kesan responden, kesulitan yang dialami dan keinginan mereka terhadap losion. Kemampuan pijat kaki juga tidak bisa dipantau, tetapi walaupun demikian, kerajinan mereka memijit tetap bisa tersalurkan dan tingkat stres mereka bisa turun.

\section{SIMPULAN}

Ada penurunan tingkat stres pada narapidana wanita setelah dilakukan pijat kaki dengan losion magnesium. Penurunan ini bisa disebabkan oleh adanya pijatan dan ditambah lagi adanya magenisum yang masuk melalui transdermal yang semakin menambah relaksasi narapidana. Penurunan ini terjadi karena individu itu yang secara aktif dan mandiri melakukan terapi dengan pijatan, bukan orang lain. Dia tahu persis kapan pijatan harus dilakukan dan seberapa banyak losion yang dioleskan. Terapi ini hanya bisa menurunkan stres tetapi tetap tidak bisa menurunkan sampai terendah atau hilang karena penyebab stres yang utama adalah vonis masa hukuman, perpisahan dengan keluarga dan kehidupan di dalam penjara. Kondisi fisik narapidana juga akan mengalami relaksasi otot dan ada kemungkinan penyakit-penyakit penyerta yang ada juga mengalami penyembuhan. Pijat melancarkan aliran darah sehingga metabolism pada area-area yang rusak, dapat dipulihkan, otot-otot menjadi pulih, emosi juga menjadi lebih tenang sehingga narapidana bisa tidur dan emosinya juga lebih terkontrol.

Metoda pijat kaki dengan losion magnesium dapat diprogramkan untuk tindakan penanganan stres narapidana di lapas terkait dengan masa tahanan narapidana yang lama yang dapat menimbulkan depresi atau stres, selain metode tindakan yang sudah dilaksanakan di Lembaga Pemasyarakatan Perempuan Klas II.A Lampung seperti tindakan disiplin, konseling, terapi kelompok, pembinaan kerohanian dan ketrampilan. Terapi pijat kaki itu sudah memberikan dampak yang positif, jadi bila tidak ada losion magnesium, bisa digantikan dengan minyak urut jenis lain sepanjang teknik urutannya benar. Terapi pijat kaki bila dilakukan di lapas, tidak hanya akan menurunkan stres dan kecemasan, tetapi juga pada kondisi fisik narapidana. Keterampilan ini perlu diajarkan dan dibudayakan di lapas. Penelitian lebih lanjut perlu dilakukan untuk memastikan kadar magnesium pada losion, teknik pijatan yang paling benar dan lamanya terapi yang dilakukan. 


\section{DAFTAR PUSTAKA}

Abdullah, A. A. (2020). Pemberian Self Help Groups Terhadap Tingkat Stres Pada Warga Binaan Pemasyarakatan Di Lembaga Pemasyarakatan. Jurnal Ilmu Kesehatan Stikes Duta Gama Klaten, 12(2).

Agus, M. A. (2020). Peran Psikologi dalam Mengatasi Stres pada Narapidana. Psikologi Penjara: Penerapan Psikologi Dalam Proses Pemasyarakatan, 101.

Anggit, F., \& Ni, A. (2017). Tingkat Stres dan Harga Diri Narapidana Wanita Di Lembaga Pemasyarakatan Kelas II A Kota Bogor. Jurnal Riset Kesehatan, 9(2), 26-33.

Arianto, A., Prastiwi, S., \& Sutriningsih, A. (2018). Pengaruh Terapi Pijat Refleksi Telapak Kaki Terhadap Perubahan Tekanan Darah Pada Penderita Hipertensi. Nursing News: Jurnal Ilmiah Keperawatan, 3(1).

Buahatika, E. (2019). Upaya Petugas Lembaga Pemasyarakatan Dalam Mengatasi Stres Pada Narapidana Di Lapas Perempuan Klas Ii B Bengkulu. [Skripsi]. Bengkulu: Fakultas Usluhudin, Adab, and Dakwah, Institut Agama Islam Negeri Bengkulu.

Chandrasekaran, N. C., Sanchez, W. Y., Mohammed, Y. H., Grice, J. E., Roberts, M. S., \& Barnard, R. T. (2016). Permeation of topically applied magnesium ions through human skin is facilitated by hair follicles. Magnesium Research, 29(2), 35-42. https://doi.org/10.1684/mrh.2016.0402

DiNicolantonio, J. J., O'Keefe, J. H., \& Wilson, W. (2018). Subclinical magnesium deficiency: A principal driver of cardiovascular disease and a public health crisis. Open Heart, 5(1). https://doi.org/10.1136/openhrt-2017000668

Gröber, U., Werner, T., Vormann, J., \& Kisters, K. (2017). Myth or reality-transdermal magnesium? Nutrients, 9(8), 813.

Heard, C. (2011). In vitro transdermal delivery of magnesium. https://doi.org/10.1017/CBO97811074153 24.004

Kass, L., Rosanoff, A., Tanner, A., Sullivan, K., McAuley, W., \& Plesset, M. (2017). Effect of transdermal magnesium cream on serum and urinary magnesium levels in humans: A pilot study. PLoS ONE, 12(4), 1-11. https://doi.org/10.1371/journal.pone.0174817

Kenner, D. (2019). Research on Transdermal Magnesium The Tides Wellness. https://www.thetideswellness.com/research -transdermal-magnesium

Kurniawati, T. (2019). Gambaran Penyesuaian Diri Dengan Stres Berdasarkan Hukuman Tindak Pidana Pada Narapidana Di Lapas Kelas Ii B Tasikmalaya. [Skripsi]: Tasikmalaya, STIKes BTH Tasikmalaya.

Manurung, I., Amperaningsih, Y., \& Kohir, D. S. (2020). Terapi Kelompok Peningkatan Kemampun Interaksi Sosial Pada Warga Binaan Lembaga Permasyarakatan Di Bandar Lampung. Sakai Sambayan Jurnal Pengabdian Kepada Masyarakat, 4(3), 168-172.

Nuraini, Y. D. (2019). Aplikasi Pijat Refleksi Kaki Terhadap Penurunan Tekanan Darah Pada Keluarga Dengan Lansia Hipertensi. [Tugas Akhir]. Magelang: Universitas Muhammadiyah Magelang.

Nuria. (2016). Perbedaan Tingkat Stres Narapidana di Lembaga Pemasyarakatan Klas IIa Jember di Tinjau dari Lama Vonis. [Skripsi]. Jember: Universitas Muhammadiyah Jember.

Oshvandi, K., Letomi, F. M., Soltanian, A. R., \& Shamsizadeh, M. (2021). The effects of foot massage on hemodialysis patients' sleep quality and restless leg syndrome: a comparison of lavender and sweet orange essential oil topical application. Journal of Complementary and Integrative Medicine.

Ruhito, F., \& Mahendra, B. (2019). Pijat Kaki Untuk Kesehatan. Repositori Riset Kesehatan Nasional.

Sarah, M. (2019). Pengaruh Kegiatan Mengkait/Merajut Terhadap Penurunan Tingkat Stres Di Lapas Wanita Klas II-A Medan: Pengaruh Kegiatan Mengkait/Merajut Terhadap Penurunan Tingkat Stres Di Lapas Wanita Klas II-A Medan. Journal of Midwifery and Nursing, 1(2 April), 30-34.

Sari, R. P. (2021). Efektivitas Terapi Pijat Kaki Tahun 2020. Nusantara Hasana Journal, 1(2), 26-36.

Siregar, R. H., Sutatminingsih, R., Saragih, J. I., \& Lubis, A. J. (2019). Stress management to reduce prisoner stress levels (Community service training in class I Tanjung Gusta prison, Medan). ABDIMAS TALENTA: Jurnal Pengabdian Kepada Masyarakat, 4(2), 324-328.

Siswati, Triana Indah \& Abdurrohim (2007). Masa Hukuman dan Stres Pada Narapidana. Jurnal Proyeksi, 4 (2), hal 95-106. 
Suwanto, A. W., Sugiyorini, E., \& Wiratmoko, H. (2020). Efektifitas Relaksasi Benson Dan Slow Stroke Back Massage Terhadap Penurunan Kecemasan Pada Pasien Hemodialisa. Indonesian Journal for Health Sciences, 4(2), 91-98.

Tiara, T., \& Lestari, A. (2017). Perilaku Caring Perawat Dalam Meningkatkan Kepuasan Pasien Rawat Inap. Jurnal Ilmiah Keperawatan Sai Betik, 9(2), 115-119.

Trisnowiyanto, B. (2012). Ketrampilan Dasar Massage. Yogyakarta: Nuha Medika.

Utomo, R. W., \& Kurniati, M. (2020). Studi Kasus Dampak Penerapan Cognitive Behaviour Therapy (CBT) Terhadap Stres Narapidana Lapas Kelas II A Bengkulu. NUSANTARA: Jurnal Ilmu Pengetahuan Sosial, 7(2), 315-324.

Welta, O., \& Agung, I. M. (2017). Kesesakan dan masa hukuman dengan stres pada narapidana. Jurnal RAP (Riset Aktual

\section{Psikologi Universitas Negeri Padang), 8(1).}

Werner, T., Weidner, M., \& Vormann, J. (2017). Transdermal magnesium-'myth or reality'? Journal of the Australian TraditionalMedicine Society, 23(4), 200-203.

Wulan, D. W. R. U. S. (2018). Hubungan Stres Dengan Kejadian Insomnia Pada Narapidana Wanita Di Lembaga Pemasyarakatan Perempuan Kelas IIB Yogyakarta. [Skripsi]. Yogyakarta: Fakultas Kedokteran, Kesehatan Masyarakat, dan Keperawatan, Universitas Gadjah Mada.

Yulyuswarni, Y. (2021). Formulasi dan Evaluasi Lotion Kombinasi Magnesium Oil dan Minyak Biji Kelor (Moringa Seed Oil). Jurnal Kesehatan, 12(1), 93-100. http://www.ejurnal.poltekkestjk.ac.id/index.php/JK/article/view/2491 